\title{
Directions, Examples, and Incentives: Slovenian Playwriting in the Second Half of the Eighteenth Century
}

Around 1860 two distinguished Slovenian cultural and political figures discussed matters of a literary nature and national importance. One of them, the young and ambitious liberal Josip Vošnjak (1834-1911), had taken up writing a verse drama; the other, the somewhat older conservative Luka Svetec (18261921), thought it was too soon for such an endeavor. ${ }^{1}$ In his opinion (which had been molded by the lyceum of the Austrian type) drama was the epitome of literature. Due to the complexity of its structure, the concentrated matter, and the necessary staging (i.e., all that went into a developed theater infrastructure), the tested capacity for reproduction, and the suitably cultured audience, drama always held a particularly representative place in the imagery and ideology of any Central European national space, transcending the artistic sphere. Impressive theatrical buildings of the nineteenth century, which were usually built in a historicizing fashion, were a monument of a sort to this very conception. They were meant to create an impression that it had always been thus.

However, only three generations earlier - a mere century - drama and theater were not concerned with such preconceptions. For Slovenes, who, as a modern national community, had not established themselves along the historicizing lines of a grand tradition and its associated appeal, but rather with a vision of an emancipated future, the forgetting of the past in the nineteenth century was somewhat understandable. Nationalistic leaders who often felt compelled to create dramatic oeuvres, thus expressing their cultural and political leadership and imposing personalities, found it helpful (at least initially) to treat the past as needing denial - and only denial. It was only later that they were able to acknowledge that they were not in fact the first to have done everything. Josip Vošnjak thus wrote a theatrical piece at the pinnacle of his career in which he quoted the entire comedy Županova Micka (Micka, the Mayor's Daughter) by Anton Tomaž Linhart (1756-1795) of 1789, adding an introduction and an ending which addressed the circumstances in which the comedy was premiered. ${ }^{2}$

1 See Josip Vošnjak. Spomini. Ljubljana: Slovenska matica, 1982, p. 88.

2 See ibid., p. 612. 
Slovenian drama of the second half of the eighteenth century certainly differed from that of the high bourgeois era in respect to what it was supposed to represent. It was certainly not limited to the idea (and nor were its creators) that it had only a literary role. In this period marked by widespread illiteracy as well as sharp censorship, drama was a synonym for a regal form that could influence the widest audience of people of different classes. As such, it attracted very diverse minds - those who wanted to strengthen the foundations of the existing order as well as those who wished for changes of different kinds.

During the second half of the eighteenth century Slovenian drama, whose corpus comprised some 2000 texts, according to one of its greatest connoisseurs, Taras Kermauner (1930-2008), at the turn of the millennium, rather quickly invaded areas where it previously could not have succeeded, since it had only existed in the form of religious and school plays. In genre it first evolved towards libretto and comedy; at the time Slovene was asserting itself as drama's only expressive medium - the age of the previously common trilingualism (which never grew into a class triglossia) almost abruptly came to an end. Anton Tomaž Linhart, who wrote his earliest works in German - among them the tempestuous drama Miss Jenny Love (1780) - turned his attention to drama in the language of his fellow countrymen.

Two older contemporaries of Linhart's, the Barefoot monk Feliks Anton Dev (1732-1786) and the curate Jurij Japelj (1744-1807), who was even appointed the bishop of Trieste before his death, only used Slovene in stage-ready verse texts. The former of the two wrote the text for the short opera Belin (1780), while the latter tried to translate into Slovene the melodrama of Pietro Metastasio Artaserse from $1730 .^{3}$ Considering that Mozart was still trying to compose the music for a text of this well known Viennese court poet right before his death, i.e. La clemenza di Tito (The Clemency of Titus) which had first been used in $1734,{ }^{4}$ it is safe to say that Japelj - at least - was trying to keep up with the times. His translation work in drama reflects his desire to introduce the successful genre of melodrama to Slovene. Since Dev created his text for the short opera Belin in a totally different style - it was a baroque allegorical play in which a 'home version' of Apollo takes the lead role - there is an implicit yet palpable critical attitude in Japelj towards his older fellow clergyman. One should point out that Metastasio was at the time considered a great authority among Slovenes, since he commended the positive impression of their language just before his death: the Ljubljana dean and Viennese freemason

3 See France Kidrič. Zgodovina slovenskega slovstva od začetkov do Zoisove smrti. Ljubljana: Slovenska matica, 1929-1938, p. 178.

4 See Jože Sivec. Opera skozi stoletja. Ljubljana: Državna založba Slovenije, 1976, p. 102. 
Janez Ricci (1745-1818), who ended his career as a titular bishop and was even awarded the Légion d'honneur in Paris during the period of the Illyrian Provinces (1809-1813), recited an Italian couplet in Linhart's translation in Metastasio's presence, which was received with great acclaim. Metastasio's verdict left a deep impression in Ljubljana. ${ }^{5}$ This is probably why Dev's Belin - the older of the two texts - received much less attention than it otherwise would have. Eventually it received only limited attention in minor or private arrangements, where it was performed to the music of a Kamnik organ player and church choirmaster Jakob Frančišek Zupan (1734-1810) - the music was considered lost until 2008. ${ }^{6}$ This lack of attention for Belin is further highlighted by the fact that it was of a decidedly cultural and reformatory character: it glorifies the victory of light over darkness, which symbolizes the introduction of Slovenian literature in the libretto. ${ }^{7}$ On the other hand, Japelj never even finished his text, which has been supposed to reveal the lack of contemporary resonance of the first original Slovenian text for a short opera.

The destiny of both Slovene libretto texts from the second half of the eighteenth century is of particular interest because it points towards a highly evolved cultural standard and its great influence on newly forged traditions. Dev is fully aware that he stands at the beginning of a certain flow of events that is growing into a tradition, while Japelj immediately sets about introducing creative paradigms from elsewhere. Yes, Metastasio's melodrama from around 1780 was no longer the gold standard and was somewhat outdated, but it was not yet complete history either. The transition periods were inevitably separating themselves from the past in their awareness of the diversity and plurality of paradigms - regardless of the prevailing ideologies of modernity that so typically glorified a very specifically designed and planned future.

In Slovenian drama, this is most evident in the opus of Anton Tomaž Linhart. His youthful desire to merge the Italian and German taste in his homeland is witness to an ambitious creator endeavoring to build something new but on the foundations of already extant and recognized traditions which provided a solid starting point and a good source of comparisons for his work as well as a certain value. Linhart never intended to author works 'on a blank slate,' thus making things easy for himself by creating an entirely new, selfmade tradition that would require new basic criteria; these were instead pro-

5 See Alfonz Gspan. “Ricci, Janez (Anton de).” Slovenski biografski leksikon. 1960.

6 See Milko Bizjak. "Prva slovenska opera Belin.” milko-bizjak, www.milko-bizjak.page.tl.// Zupanova-opera-Belin.htm. Accessed 11 June 2018.

7 See Feliks Anton Dev. "Vesele krajnskeh modric na prihod njeh Belina.” Pisanice 1779-1782, edited by Lino Legiša. Ljubljana: Slovenska akademija znanosti in umetnosti, 1977, pp. 54-65. 
vided by an already valid qualitative standard. In one of his letters to Martin Kuralt (1757-1854) he maintains that he is not foolish or arrogant enough to claim an important title in Europe; ${ }^{8}$ yet this was no obstacle to him adopting the highest examples, or rather their emblems, for his dramatic beginnings. His Miss Jenny Love, a tempestuous drama published in 1780 in Augsburg, was supposed to follow in Shakespeare's steps. ${ }^{9}$ This applies particularly to the diversity of action (which leads to the tragic end of the main characters due to the demonic Lord Herington) and the use of external scenes, and quite possibly the setting of the textual microcosm in Britain - an homage, to be sure. However, the lack of long monologues steers away from the Shakespearean example.

In the spirit of his merging of German and Italian inspirations Linhart printed his collection of poems Blumen aus Krain (Flowers from Carniola) a year later; if Miss Jenny Love exhibited his knowledge of literary practices in the German north, he now turned his attention to the Latin south of Europe. This meant opening the doors to the more conservative conceptions of the stage. It seems that Linhart paused at Metastasio, too - but not at the historically 'grounded' melodrama (as Japelj did) but at the azione teatrale; ${ }^{10}$ based on his two-act drama L'isola disabitata (The Desert Island), which is a prime example of the genre (and was also put to music by Franz Joseph Haydn), Linhart wrote the German text Das öde Eiland for a song play. However, by doing so he did not change his aesthetic credo: the rhythm of change in music theater is different from that in drama. The Blumen aus Krain collection is an interesting case of stylistic adaptation to other genres. Linhart's very diverse book exhibits texts of the 'last shift' style (a representative case is the German translation of the Slovenian romance Pegam in Lambergar; Pegam and Lambergar), but also some versifications done according to other ideals of form and thought. However, these were only the first steps on the author's path, which was paved by the need to unify the European republic of thought in his homeland. Following this path he also took into account some English (Pope) and French authors (Montesquieu, Beaumarchais).

Unfortunately, the next work by Linhart - a drama about an adventurous major John André, who was ordered to be hanged by George Washington in 1780 - is known by title alone. ${ }^{11}$ It was entirely contemporary, but it also addressed interesting issues of loyalty and treason in a time of radical changes.

8 See Anton Tomaž Linhart. Zbrano delo. Ljubljana: Državna založba Slovenije, 1950, vol. 1, p. 408.

9 See ibid., p. 331.

10 See ibid., p. 498.

11 See Mirko Zupančič. Literarno delo mladega A. T. Linharta. Ljubljana: Slovenska matica, 1972, p. 98. 
Yet Linhart, who subscribed to the enlightenment philosophy (even though he initially wanted to become a priest, he later doubted that just reading the Bible could make a man happy ${ }^{12}$ ), evidently could not find sufficient support for his literature - and his work was not financially viable enough to finance an independent publishing activity. If he wanted to maintain his literary activity (he was also interested in history), he desperately needed support. After his failed attempt to form an intellectual circle - a scientific academy whose members would be drawn from the local aristocratic and intellectual elite - his only remaining option was to join the circle of the baron Sigismund Zois (17471819). The wealthiest man in Carniola, Zois was a known supporter of the Muses whose rich library provided the basis for scientific and literary activity on the southeastern rim of the Austrian monarchy.

The baron Zois, who had been brought up intellectually in Italy, was a reformer. ${ }^{13}$ Though he subscribed to some initiatives of French philosophers, he thought that circumstances at home needed special impetuses to make the world better. Linhart pictured his homeland as a junction of different cultures from which a new original tradition would spring up; however, despite some differing positions, he did not contest Zois's views. Zois's ardor for his mother tongue, which he understood as a tool for improving the microcosm, directed Linhart towards writing for the stage in Slovene. This was by no means a change of heart, since the last two plays written by Linhart still exhibit his devotion to the idea of a European synthesis in his homeland. However, what changed was the strategy that was supposed to lead to this effect: the need to change the world was directed to the most general addressee possible. His eagerness for his homeland, which was close to his heart even during the writing of the Blumen aus Krain, was now addressed to what was, linguistically and factually, its most numerous population. At first sight it seems paradoxical that Baron Zois, a descendant of a knighted bourgeois, directed Linhart towards the knowledge that changing the world starts with 'people without qualities'; yet the entrepreneur who only had the market to thank for his fortune could nurture no illusions about the quotidian source of his well-earned wealth, despite his belonging to the intellectual and class elite. Of course, the American and French revolutions, about which Ljubljana was well informed, as well as personal liberties - the most important result of the endeavors of the reformist emperor Joseph II - also produced their effects.

12 See Anton Tomaž Linhart. Zbrano delo. Ljubljana: Državna založba Slovenije, 1950, vol. 1, p. 432.

13 See Lino Legiša, and Alfonz Gspan. Zgodovina slovenskega slovstva I.: Do začetkov romantike. Ljubljana: Slovenska matica, 1956, pp. 379-382, p. 392. 
The comedies Županova Micka and Ta veseli dan ali Matiček se ženi (This Happy Day, or Matiček Gets Married) were published in 1790 in Ljubljana; they are an expression of an eager, in many respects even combative literature which features emancipatory thinking. The Županova Micka, an adaptation of Joseph Richter's comedy Die Feldmühle (The Country Mill) of 1777 which was performed by traveling theater groups in Carniola on many occasions, is a critique of a morally depraved, frivolous nobleman which ends with mockery at his expense: it is peasants who set things straight with the aid of a 'noble lady.' The nobleman, however, is aided by a drunkard village scribe - which means there is no black-and-white division among characters according to class. Yet the aim of the play, which was first staged in 1789 in Ljubljana, was inevitably to point out that individual solutions to problems of dejectedness and dishonesty are basically impossible. Micka, who wants to be elevated in class, can only become a victim to a con-man.

Linhart's adaptation of Beaumarchais's comedy La Folle Journée, ou le Mariage de Figaro (The Mad Day, or The Marriage of Figaro) (which came just a year later) is much more ambitious. Since the Slovene version of this famous work, which Napoleon thought to be the revolution underway, was created in the period of increasing antagonisms between the French revolutionists and the ancienne Europe, additional attention was required from the Slovenian adaptor - and swiftness, too, since the text was published just in time before stricter censorship was enforced in the Habsburg Monarchy; the latter was a consequence of the growing fear of sympathies for the revolutionaries in Paris, whose incredible cruelty was dramatically reported even in Slovenian 'news poetry,' i.e. a sort of oral 'newspaper' for the illiterate peasantry. Singing inserts in the Ta veseli dan ali Matiček se ženi indicate the possibility that Linhart, a musical talent and himself a composer, followed the example of Lorenzo Da Ponte's libretto adaptation of Beaumarchais's work written for Mozart and his Le nozze di Figaro of 1786. The counter-feudal emphases in the Slovenian version are somewhat less pronounced than in the French original; however, they are still very explicit and visible also outside the stage situation. A recognizable feature is Linhart's aversion to German bureaucracy, which is obviously absent in Beaumarchais. In this respect the Ta veseli dan ali Matiček se ženi is more than a mere critique of aristocracy; it is also a critique of germanizing tendencies that became quite pronounced in the Austrian Monarchy during the reign of Emperor Joseph II. Linhart, who first enthusiastically supported the reforms of the enlightened monarch, ${ }^{14}$ evidently came to realize that these

14 See Anton Tomaž Linhart. Zbrano delo. Ljubljana: Državna založba Slovenije, 1950, vol. 1, p. 450 . 
were ultimately condemned to fail due to the neglect of local circumstances. The unfortunate ruler, who was forced to overrule most of his reforms on his deathbed if he wanted his brother Leopold II to inherit anything other than complete chaos, met the limits of his absolutism - particularly in Hungary. The imagery and ideology of the emperor and those under him were now in almost complete opposition. The enforcing of German administration in the region that was in language exclusively Slovene pushed Linhart towards the circle of the counter-Josephine coalition shaped by conservative clergy and aristocracy from different provinces of the Habsburg Monarchy, together with enlightened counter-centralists and the advocates of the newly discovered spirit of nations. It is therefore far from odd that the comedy Ta veseli dan ali Matiček se ženi was first staged only on the eve of the March Revolution in $1848 .{ }^{15}$ The regime of Leopold II was, despite its character of enlightened absolutism, already so afraid of people that it established a secret police for the purpose of control a service that would later infiltrate all segments of the complex Austrian Monarchy. However, it failed to fulfill its purpose; Linhart's subversive version of Figaro, the Ta veseli dan ali Matiček se ženi, was reprinted even during the period of the strictest absolutism of Klemens Metternich (1773-1859) - for which a 'camouflage' as a grammar example came in very handy.

Slovenian drama of the second half of the eighteenth century decreased in activity considerably during the period of Metternich's absolutism, which treated very suspiciously any initiative 'from below,' yet it provided the basic platform for the subsequent playwriting in the region between the Alps and the Adriatic. While German and Italian stage managers usually drew on plays from elsewhere, Slovenes had no other options than to resort to domestic production, which consequently became nationally representative - the ideology of (high-)school poetics was not the only reason for this. Through the process of evolution from adaptation to originality, creative production for the stage remained mindful of qualitative standards, despite the performance amateurism that lasted almost until the end of the nineteenth century, even though it failed to become the European synthesis in Linhart's sense. But, then again nobody managed to achieve that anywhere else either.

15 See Lino Legiša, and Alfonz Gspan. Zgodovina slovenskega slovstva I.: Do začetkov romantike. Ljubljana: Slovenska matica, 1956, p. 400. 
